\title{
Metaphoric Perceptions of School Principal Candidates: Being a School Principal
}

\author{
Ali Erden", Hale Erden ${ }^{2}$ \\ ${ }^{1}$ Internatinal Final University, ORCID ID: 0000-0001-7190-4144 \\ Email: ali.erden@final.edu.tr \\ 2Internatinal Final University, ORCID ID: 0000-0003-4177-6203 \\ Email: hale.erden@final.edu.tr
}

\begin{abstract}
The purpose of this research is to determine the perceptions of vice-principals and teachers, who are candidate principals, about being a school principal through metaphors. For this purpose, the candidate principals produced metaphors regarding the concept of being a school principal. In the qualitatively designed research, phenomenology the research design used. The vice-principals and the teachers attending the series of in-service training courses held for candidate principals in Nicosia during the 2018-2019 academic year constituted the study group of the study. Research data were collected using a semi-structured interview form. The semi-structured interview form included the metaphorical definition of the school principal and the reason to produce the mentioned metaphor. To analyze the data content analysis method was applied. The perceptions of the candidate principals revealed twenty-six metaphors regarding the concept of being a school principal. These metaphors were gathered under nine categories by the researchers. The produced categories namely are guiding school principal, protecting school principal, diligent school principal, negatively behaving school principal, balancing school principal, superior power user school principal, acting school principal, the school principal as the source of information and indispensable school principal. The most produced metaphor by the candidate principals is called a school principal is a conductor. A school principal is similar to a commander, an orchestra conductor, a theatre artist, a bull, a mirror, a clock, a mother/father, a bridge, an acting, a state, a lion, a nervous system and a building foundation. To determine a series of metaphors classified under eleven categories and the most repeated metaphors were classified under the guiding school principal category.
\end{abstract}

Key words: School principal, metaphor, candidate principals, leadership

\section{Introduction}

Contemporary theorists argue that there is more to mention about metaphors than explaining in simple words. Metaphors are the words allowing us to think of one thing in terms of another description. We can understand something new because we can connect it to something we know or understand. Unknown concepts become understandable and known through metaphors (Brandt, 2004). Particularly, metaphors enable people to understand and experience one thing using another figurative way (Lakoff and Johnson, 2003). To explain or interpret reality requires the usage of metaphors (Lunenburg and Ornstein, 2012). Metaphors are abstract elements shaped by the perceptions of living beings, images of objects, and human beings associated with daily life experiences. The universe of meaning belonging to metaphors, as a field that carries traces from concrete experiences, also reveals the relationship established directly with objects (Abdal, 2017). In other words, by examining metaphors, we begin to perceive our cultural and physical experiences (Hogler et al., 2008).

Since metaphors reflect a different view and vision on how we better understand the world, leveraging these potential tools can be beneficial in improving our perceptions and understanding of a complex and contradictory phenomenon, such as organizations. Morgan (1997) states that metaphors are the cornerstones of our tolerances and our judgments as a way of thinking and understanding perceptions, all the theories about organizations are metaphors in nature. Managers make progress through gaining knowledge and promoting knowledge about an organization using the metaphors and practices produced by Morgan (1997). Metaphors have a cognitive, theoretical, and didactic function in organizations, and they provide a better understanding of organizations (Chatelain-Ponroy, 2010). Admittedly, a metaphor allows re-conceptualizing, meaning to a term under the influence of a concept belonging to another domain through the cognitive function. A metaphor plays an inseparable and irreplaceable role in a theory or discipline through the theoretical function. Finally, in the didactic function, it is possible to explain 
information from a known field, applied since Aristotle, by employing it through an unknown path. Thus, it helps to understand the obscure area.

Moreover, Itkin and Nagy (2014) explained that the metaphors produced by Morgan (1997) are effective in helping us to figure out the structures of organizations, their leadership styles, their management behavior, and the type of control by adding meaning to them. They also argued that, due to the multidimensional nature of metaphors, multiple aspects of organizations emerged, leading to the expansion of our knowledge, views, and visions. They need to do more research to explore how to apply metaphors in various local organizations, political organizations, hospitals, and universities.

Three communicative functions of metaphors set as effective expression/compactness, inexpressiveness, and liveliness. The compactness function of metaphors is on a restructuring understanding of language. The metaphor of compactness enables predicting a set of properties that requires a long list of properties specified separately in one or two words. People can explain ideas in a more detailed and effective/compact manner with metaphors. The inexpressiveness metaphor makes it possible to predict by transferring its unnamable properties. The last hypothesis, called liveliness, says that metaphors make statements clearer (Ortony, 1975).

Lakoff and Johnson (2003) mentioned three types of metaphors within the framework of metaphor theory: Ontological metaphor, structural metaphor, and intentional metaphor. The concept of ontological metaphor includes the act of giving concrete features to abstract concepts and ideas. The ontological metaphors with cultural characteristics are directly related to individual experiences. Structural metaphor is one of the concepts giving structure to another. Building metaphors work with an internal system in accordance. However, this systematicity is limited, as is the nature of the metaphor. The intentional metaphor with real actualization of embodied concepts produced by individuals in textual usage and the intentional metaphor with indigenization/alienation has a close connection to the metaphorical rewriting process. The source field of orientation metaphors after concepts that usually indicate involves a space. The concepts indicating spaces are as follows: up-down, in-out, anteroposterior, deep-shallow, centerperiphery. Such metaphors are on bodily experience. The orientation concepts have existed due to the kinds of bodies we own. Our body acts as a reference point or reveals experiences. Therefore, the space within the framework of these concepts, according to the experiences it has experienced while moving.

Botha (2009) stated that the use of educational metaphors is in the following areas.

1. Metaphors can create the educational policies we design, such as metaphors on market metaphor or school choice (goods, services, consumers).

2. It can be related to the teaching process (such as teaching as regulation, conditioning, guidance, or training).

3. They can function intuitively as an exploration tool (spiral staircase or ladder).

4. They usually function didactic as part of teaching approaches (dramatization and role-playing).

5. They characterize the teaching actions of the teacher (pottery, gardener, artist, police, entertainer, preacher, scholar, guide, coach, researcher, sculptor, conductor, gardener, wife, etc.).

6. They determine what the learning process will look like (sponge, filter, funnel, strainer).

7. They characterize the content of the subject taught and the curriculum (system, mechanism, organism).

8. Metaphors can function as communication tools.

9. Metaphors mediate understanding of the nature of the school (family, factory, etc.) as an educational institution.

Metaphors directly affect our negotiations and relationships at the personal level, which conversely affect the processes regarding educational administration.

The nature, emergence, and emphasis of metaphors in educational administration are vital for administrators to understand interpersonal relationships, which has importance for the school climate (Tomlinson, 2004). A metaphor, a powerful tool for designing many aspects of the hidden world of learners and teachers, the interested educational parties, affects concepts and processes educationally. Educational concepts and processes are described metaphorically (Low, 2008). Brooks and Normore (2010) evaluated the new roles of school administrators for the training of education leaders for 21st-century schools. They argued that contemporary education leaders should develop global literacy skills under nine specific areas of knowledge: political literacy, economic literacy, cultural literacy, moral literacy, pedagogical literacy, information literacy, organizational literacy, spiritual and religious literacy, and temporal literacy. Moreover, each of these areas of literacy is dynamic, interconnected, and influenced by different representatives of education leaders. Various behaviors of school administrators are perceived, monitored, and interpreted by the groups they are in contact with. As appeared in human minds, others can note for meaning. There are various ways to express mental perceptions. One of these different ways of interpretation includes metaphors. 
Beck and Murphy (1993) agreed on how the image of the school principal changed between 1900 and 1990. They also found that in the 1900s principals were seen as teachers with administrative responsibilities and as guardians of accepted values. By the 1920s, the dominant opinion in the school principal was the scientific administrator. However, a series of numerous references had the spiritual and religious values of the principals in many sources. These references disappeared in the 1930s, and the principals in an organization and school administrators took the attention. Principals in the 1940s and 1950s were leaders of democratic schools, whereas the principals in the 1960s were required to use proven strategies for excellence. The director of the 1970s was the person who leads the way in solving social problems. In the 1980s, principals run schools to encourage the development of a stable economy. The early 1990s were part of the second wave of education reform as a restructuring movement. The metaphors identified for the reconstruction movement listed as follows: a leader, a servant, an organizational architect, a social architect, an educator, a member of society and, a moral agent.

To be assigned as a principal in the education system of North Cyprus, it is required to serve full-time as a governmental primary teacher for at least ten years and teach full-time as a governmental secondary school teacher for at least fifteen years. The appointment of the principals and vice-principals resulted through the intervention criteria evaluation and the ranking determined as a result of the exam with the amendment made in the Teachers Examination Regulation dated 28 February 2019. Criteria evaluation for the candidate principals in the education system of North Cyprus consists of seniority, registration, professional development courses, scientific activity-publication, and social-cultural activities. Written multiple-choice promotion exam includes education management, legislation, general culture, English, and ICT subjects shown in Table 1 (Yükselme Sınavını Olușturan Testlerin Kapsamı, 2019).

Table 1. Topic Distribution of the Topics of Written Promotion Exam in North Cyprus

Topic Distribution Primary Education, Secondary Education, Vocational-Technical Education

\begin{tabular}{ll}
\hline Education Management & 160 \\
\hline Legislation & 180 \\
\hline General Culture & 40 \\
\hline English (Intermediate Level) & 10 \\
\hline Computing Skills (ICT) & 10 \\
\hline Total & 400 \\
\hline
\end{tabular}

According to the same regulation, candidates who fail to get at least fifty percent in the written examination and who cannot achieve 600 or more in total cannot enter the placement list (article 14/3). As a result of the written promotion exam and criteria evaluation, the candidates are entitled to appointment to the vacant teacher positions by the Public Service Commission (article 18/1). Again, according to this regulation, the Ministry of Education regularly organizes in-service training courses required in educational management sciences and other related branches every year. Various studies have been conducted on the metaphorical view of the school principals. These studies were conducted by prospective teachers (Çobanoğlu and Gökalp (2015), Örücü (2014), Akyol and Kapçak (2017), by students (Şahin and Tüzel (2014), Aslan, Bilgili and Kaya (2018), Akbaşlı, Üredi, Yolcu, and Loğoğlu (2017), by teachers (Korkmaz and Çevik (2018), Akan, Yıldırım and Yalçın (2014) and by school administrators (Demirtaş and Özer (2014).

In Northern Cyprus, vice-principals and teachers desire to be a school principal. For this purpose, they participate in-service training and engage in social activities. We cannot explain this only with the small increase in income as a result of school principalship. Here, personal wishes, environmental effects and goals to be achieved are also effect their desire. Metaphors will help us in understanding these effects. There is no study in the literature conducted with vice-principals and teachers who attend the series of in-service programs to meet their goal. In addition, collecting data through metaphors is one of the most effective data collection methods to understand the variables motivating the candidate school principals. With this study, it is a matter of trying to understand the reasons leading the vice-principals and teachers requesting to become school principals through metaphors. 
To determine the perceptions of the candidate principals through metaphoric usage is the purpose of the current study. Candidate principals are vice-principals and teachers.

Answers given to the following questions are maintained to achieve the purpose:

1. What are the metaphors that prospective school principals have regarding the concept of principalship?

2. Under which common conceptual categories are the produced metaphors grouped using their features?

\section{Method}

The current study aims to reveal perceptions regarding candidate principals about the concept of principalship in North Cyprus through metaphors, the phenomenology design, one of the qualitative research designs, was used.

\section{Research Model}

Phenomenology design is a qualitative research design that aims to make sense of the facts with different perspectives by determining the experiences and meanings of the participants. This research method is on making direct sense of the meaning or nature of their daily experiences in depth by the individuals (Patton, 2002; Creswell, 2003; McMillan, 2004). The phenomenological approach is a type of qualitative research suitable for studying decisive, emotional, and intense human experiences (Merriam, 2009). The phenomenological pattern aids the researcher in building a description of the situation and developing the bridges between the different interpretations emerging from the event. Throughout the process of the phenomenological pattern, defining the case to be studied, describing the experiences of the person concerned, and collecting information from various people experiencing the circumstances seems important (Moustakas, 1994).

A metaphor is a linguistically expressed item transferred from a field of application. This transmission serves the purpose of establishing a particularly appropriate description of the characteristics of the target area where setting no targets to disclose like a black hole, or none are deemed appropriate (Jones, 2002). Black (1979) also argued that a figurative statement leads to new knowledge or understanding of the subject under consideration.

Instead of directly questioning the perceptions of the candidate principals, data collection was conducted through metaphorical usage to create an opportunity for the participants to reveal their views, beliefs, and perceptions indirectly. The usage of metaphors generally aids in communicating the meaning and transferring passion about the topic (Carpenter, 2008; Sandelowski, 1998).

\section{Study Grup}

The purposive sampling method has been beneficial in selecting the studying group for the current study. For this purpose, teachers, and vice-principals participating in the Professional Development Program of School Administrators in the Context of Inclusive Education, designed and applied by the TRNC Ministry of National Education and Culture between 4-9 November 2018 by following Article 8 under the Teachers Examination Regulation, constitute the study group of this research.

Table 2. Demographic Information of the Candidate School Principals

\begin{tabular}{llll}
\hline & Groups & $\mathrm{N}$ & $\%$ \\
\hline \multirow{3}{*}{ Sex } & Female & 24 & 75 \\
& Male & 8 & 25 \\
& Total & 32 & 100 \\
\hline \multirow{3}{*}{ Status } & Vice Principal & 9 & 28,1 \\
& Teacher & 23 & 71,9 \\
& Total & 32 & 100 \\
\hline \multirow{3}{*}{ School Type } & Primary & 7 & 21,9 \\
& Secondary-High School & 25 & 78,1 \\
& Total & 32 & 100 \\
\hline
\end{tabular}

$75 \%$ of the participants are women, and $25 \%$ of them are men. In TRNC, the number of female teachers is higher when compared to male teachers. For example, in the 2019-2020 academic year, there are 2748 female teachers and 1253 male teachers in public schools in the TRNC education system. In other words, $31.32 \%$ of those working in the education system are male teachers, while $68.68 \%$ are female teachers (eohd.mebnet.net, 2020). 
Most of the participants are entitled to teachers. There are 179 teachers entitled to vice-principals in the system in the 2019-2020 academic year (eohd.mebnet.net, 2020). 78.1\% of the participants serve in secondary education. In the 2019-2020 academic year, 2407 teachers teach in the public secondary schools, while 1594 teachers teach in primary schools (including special education and pre-schooling) (eohd.mebnet.net, 2020).

\section{Data Collection Tools and Procedure}

To determine the metaphors they produced for the concept of being a school principal, the researchers asked the candidate principals to fill in the blanks regarding the following question format: School principal is similar to ...........; because ............ . A semi-structured form, an interview consent form, was used. The reason for asking the participants to explain why they produce the metaphor, the metaphors used alone may not be sufficient to fulfill the given communicated perception; therefore, the communicated perception, the purpose of the metaphors produced, aimed to interrogate kindly for a valid reason. To categorize the data through the content analysis method, the research question determines what to insight and create further (Elo and Kyngäs, 2008). Content analysis is one of the systematic and objective ways to describe phenomena and analyze the relationships of concepts (Schreier, 2012). The research question determines what to analyze and what to create (Elo and Kyngäs, 2008; Schreier, 2012). The abstraction process in qualitative content analysis is the stage to produce concepts.

Generally, identifying some aspects of the process becomes easy, which conversely depends partly on the insight of the researchers or intuitive action (Elo and Kyngäs, 2008; Graneheim and Lundman, 2004). A prerequisite for successful content analysis concerns the data reduced to concepts to define the research phenomenon through creating categories, producing a series of concepts, designing a model, programming a conceptual system, or a conceptual map. Inductive or deductive usage of qualitative content analysis is possible. The inductive and deductive content analysis processes involve three main stages: preparing, editing, and reporting results. The preparation phase consists of collecting appropriate data for content analysis, interpreting the data, and selecting the analysis unit. In the inductive approach, the organization phase includes open coding, category creation, and abstraction (Elo and Kyngäs, 2008). In deductive content analysis, the organization phase involves developing a categorization matrix, where all data are analyzed in terms of content and coded for conformity to defined categories or sampling (Polit and Beck, 2012).

The classification matrix can be valid if the categories adequately represent the concepts, and in terms of validity, the categorization matrix accurately captures the intended purpose (Schreier, 2012). In the reporting phase, results defined by the content of the categories describe the phenomenon using a chosen approach (deductive or inductive).

\section{Data Analysis}

A five-staged analysis method applied in metaphor studies: Teachers developed the metaphors and sentences in the naming stage to examine. The metaphors produced are listed in alphabetical order. Concepts counted as metaphors have been confirmed and marked by the educational field expert. During the screening phase, the unrelated metaphors produced by the participants put aside the evaluation. Accordingly, the data produced by four teachers left aside in the scope of the study. Thirty-two viceprincipals and teachers who produced data with metaphors were included in the study. To perform the necessary processes, the subjects and sources of each of the metaphors were produced and, the relationship between the subjects and sources of the produced metaphors were taken into consideration. At the category stage, nine different conceptual categories were created by examining the metaphors produced by the teachers, their common features, and qualities regarding the concept of being a school principal.

\section{Ethical}

The similarity rate was to determine the reliability of the study by consulting the opinion of the educational expert. For this purpose, the researchers gave a list containing the metaphors in alphabetical order and a list containing the names and characteristics of different categories to the educational expert. To compare both of the lists, the researchers asked the educational expert to match the list containing the metaphors with the list containing the different categories. The researchers also matched the list containing metaphors with the list containing the different categories. Miles and Huberman's (1994) formula to calculate the reliability of the research in comparisons was applied as follows: (Reliability Coefficient=Consensus/Consensus+Disagreement). The opinion by the educational expert linked the two metaphors by placing them in different categories. Accordingly, a consensus of $98 \%$ 
(Reliability $=100 /(100+2)=0.98)$ was calculated in the reliability study regarding the concept of principal. According to the coding control, which gives internal consistency, the consensus between the coders is to be at least $80 \%$. A full consensus was achieved through making corrections together in matches with disagreement. The frequency (f) values of the data were calculated. In addition, the vice-principals in the research were entitled VSP1, VSP2, and the teachers were called T1, T2, T3.

\section{Findings}

In this section, the metaphors produced about the principalship and the categories created are determined.

\section{Metaphors of Candidate Principals for the Concept of Principalship}

Findings of the research revealed that the metaphors produced by the principal candidates for the concept of principalship and the number of candidate principals representing them (f) are explored in Table 3.

Table 3. Metaphors Produced Regarding the Concept of Principalship and the Number of Candidate

\begin{tabular}{|c|c|c|c|c|c|}
\hline No. & Metaphors Produced & Frequency (f) & No. & Metaphors Produced & Frequency (f) \\
\hline 1. & Commander & 1 & 14. & Hitler & 1 \\
\hline 2. & Orchestra Conductor & 4 & 15. & Octopus & 1 \\
\hline 3. & Theather Artist & 1 & 16. & Panda & 1 \\
\hline 4. & Bull & 1 & 17. & Atom Ant & 1 \\
\hline 5. & Mirror & 2 & 18. & The Nucleus of the Atom & 1 \\
\hline 6. & Clock & 1 & 19. & Householder & 1 \\
\hline 7. & Mother/Father & 1 & 20. & Compass & 1 \\
\hline 8. & Bridge & 1 & 21. & The Root of the Tree & 1 \\
\hline 9. & Acting & 1 & 22. & Soldier & 1 \\
\hline 10. & State & 1 & 23. & Driver & 1 \\
\hline 11. & Lion & 1 & 24. & Captain & 1 \\
\hline 12. & Nervous System & 1 & 25. & Tree & 2 \\
\hline 13. & Building Foundation & 1 & 26. & Bee & 1 \\
\hline \multicolumn{3}{|c|}{ Total Number of Candidate Principals } & \multicolumn{3}{|c|}{32} \\
\hline \multicolumn{3}{|c|}{ Toptal Number of Metaphors } & \multicolumn{3}{|c|}{26} \\
\hline
\end{tabular}

As seen in Table 3, teachers produced twenty-six different metaphors related to the concept of principalship by the teachers and vice-principals who are principal candidates. It is seen that the metaphor most frequently developed by principal candidates is called conductor $(f=4)$. Various metaphors produced were developed by one to two teachers.

Categories Created by the Metaphors by the Principal Candidates Regarding the Concept of Principalship 
The classification of the types of metaphors produced by the principal candidates regarding the concept of principalship in terms of their common qualities and features is given in Table 4 .

Table 4. Distribution of Metaphor Categories Produced by the Candidate Principals

\begin{tabular}{|c|c|c|c|c|}
\hline Categories on & $\begin{array}{l}\text { Frequencies } \\
\text { of } \\
\text { Metaphors } \\
(f)\end{array}$ & $\begin{array}{l}\text { Percentages } \\
(\%)\end{array}$ & $\begin{array}{c}\text { Metaphors } \\
\text { produced by } \\
\text { Vice-Principles }\end{array}$ & $\begin{array}{c}\text { Metaphors produced } \\
\text { by Teachers }\end{array}$ \\
\hline Guiding School Principal & 11 & 34,37 & $\begin{array}{l}\text { Condutor(2), } \\
\text { Mirror }\end{array}$ & $\begin{array}{l}\text { Conductor(2), Mirror, } \\
\text { Octopus, Compass, } \\
\text { Driver, Captain, } \\
\text { Nervous System, }\end{array}$ \\
\hline Protecting School Principal & 4 & 12,5 & Mother/Father & $\begin{array}{l}\text { Householder, Head of } \\
\text { the Family, State }\end{array}$ \\
\hline Diligent School Principal & 4 & 12,5 & Clock & Bee, Atom Ant, Tree \\
\hline $\begin{array}{l}\text { Negatively Behaving School } \\
\text { Principal }\end{array}$ & 4 & 12,5 & Sitting Bull & Hitler, Panda, Soldier \\
\hline Balancing School Principal & 2 & 6,25 & $\begin{array}{l}\text { Bridge } \\
\text { Commander }\end{array}$ & --- \\
\hline $\begin{array}{l}\text { Superior Power User School } \\
\text { Principal }\end{array}$ & 2 & 6,25 & --- & $\begin{array}{l}\text { Lion, Building } \\
\text { Foundation }\end{array}$ \\
\hline Acting School Principal & 2 & 6,25 & Theatre Artist & Acting Person \\
\hline $\begin{array}{l}\text { The School Principal as the } \\
\text { Source of Information }\end{array}$ & 2 & 6,25 & --- & $\begin{array}{l}\text { TheRoot of a Tree, } \\
\text { Tree }\end{array}$ \\
\hline Indispensable School Principal & 1 & 3,13 & --- & $\begin{array}{l}\text { The Nucleus of an } \\
\text { Atom }\end{array}$ \\
\hline
\end{tabular}

Total

32

100

According to Table 4, the metaphors developed by the principal candidates regarding the concept of principalship were categorized under nine categories in total.

The category of guiding school principal got the highest number among the metaphors produced by the candidate principals $(f=11)$. Similarly, the category of indispensable school principal got the least number among the metaphors produced by the candidate principals $(\mathrm{f}=1)$. However, the number of metaphors of the remaining categories varied between 2 and 4 .

\section{Guiding School Principal Category}

According to Table 4, three vice-principals and eight teachers produced seven metaphors in the guiding school principal category. In this category, the metaphors of conductor, mirror, octopus, compass, driver, nervous system, and captain were used.

Below are sample expressions produced by the candidate principals in this category as follows:

"The headmaster is like a conductor. It ensures that all units, staff, teachers, parents, and students are in harmony with each other/ He should be knowledgeable while managing the institution, who can see and 
correct the mistakes that everyone communicates and can act together with the members of the orchestra to correct them (VP2)."

"The headmaster is like a mirror. Because the person shows the result in his actions. It reflects itself (VP5)."

"The principal is like an octopus. Because it helps in every job (T18)."

"The headmaster is like a compass. Because it should show direction and help achieve the determined goals (T24)."

"The principal is like an experienced driver. Because with its experience and knowledge, it leads to where it needs to go to school (to manage properly). With his knowledge and skills, he knows what to do in the face of the events he encounters, makes the right decision, or ensures the right decision collectively (T29)."

"The school principal is similar to the nervous system. Because the nervous system has a structure that responds to the vital functions of a living thing, detects faulty data coming from outside and the environment, and develops a defense mechanism accordingly. .... (T14)."

"The headmaster is like a captain. Because the education system is a whole consisting of more than one person and component. The person who will guide this system and contribute to the implementation of the determining system in schools is the school principals. Just like the captain who determines the required route for a ship to sail (T30)."

\section{Protecting School Principal Category}

According to Table 4, a vice-principal and three teachers produced four metaphors in the protecting school principal category. In this category, the metaphors of mother/father, householder, head of the family, and state were produced. Below are sample expressions of the vice-principal and teachers who produced the metaphors in this category.

"The school principal is similar to the mother/father of the house. Because running the school is like running the house. It must be possessed, and if necessary, it must be able to sacrifice time for itself. Such as the mother/father's supposed and/or actions at home towards their children. For example, he should never discriminate, behave fairly. He must love his employees as he loves his children, value them, and make them feel this. In the meantime, when necessary, he/she should objectively evaluate what everyone does or does not do and reward/penalty, etc. Applications such as should do. The main thing should love his job (VP8)."

"A school principal is like the head of a family. Because just as ahead of a family is responsible for his family, a principal is responsible for all kinds of work of the school (T23)."

"The school principal is like a family man. Because the administration, teachers, and students are members of the family (T25)."

"The school principal is like a state. Because the primary point of the state's first justice is the schools before the courts. And when schools are delivered to those who do not see the state as a state, they aim to raise people with different ideologies and beliefs, not for the nation (T12)."

\section{Diligent School Principal Category}

Table 4 reveals that a vice-principal and three teachers produced four metaphors in the diligent school principal category. In this category, the metaphors atom ant, bee, clock, and tree were used. Below are the sample statements of the teachers who produced the metaphors in this category.

"The director is like an atomic ant. Because it works tirelessly (T21)."

"The school principal is like a bee. Because it works non-stop (T32)."

"The warden is like a clock. Because it has to work constantly to keep things running smoothly. It will give the wrong time like the clock stops or slows down. If the principal does not make the right decisions and is not for permanent domination, the functioning of the school will be disrupted (VP7)."

"The principal is like a tree. Because its roots have to reach everywhere (T27)."

\section{Negatively Behaving School Principal Category}

According to Table 4, four metaphors were produced by two vice-principals and two teachers in the negatively behaving school principal category. In this category, the metaphors of sitting bull, Hitler, soldier, and panda are used. Below are sample expressions of the vice-principal and teachers who produced the metaphors in this category.

"The headmaster is like a sitting bull. Because the status he received as matador is known for the sub-staff to do all the work, the principal is only at school to approve the signature meeting and the approval of the resolved status of the problems (VP4)." 
"The school principal is similar to Hitler. Because they have the logic that whatever I say happens (VP7)."

"The headmaster is like a panda. Because he transfers all the work (including administrative powers) to the assistants and comes and goes to school arbitrarily. Sometimes it does not come (T20)."

"The headmaster is like a soldier. Because he fulfills the duties he has taken from superiors (T28)."

\section{Balancing School Principal Category}

According to Table 4, two vice-principals produced two metaphors in the balancing school principal category. The metaphors of bridge and commander were produced in this category. Below is the sample statement of his assistant who produced the metaphors in this category.

"The headmaster is like a bridge. Because it regulates the flow of education. Roads coming from students, teachers, parents, and ministries usually cross and find direction at this point. The stronger functional the structure and operation of this bridge, the more regular the training traffic (VP9)."

"It compares the headmaster to the commander. Because, in our schools, performance evaluation, the reward is not punishment, so it is necessary to carry out the system in a disciplined manner. In addition to the teachers who do not attach importance to education and training due to the gaps in the system, unfortunately, I think it is necessary to think about a little hard to balance the teachers who develop themselves in this system and to understand its importance. This is necessary while teaching and valuing students (VP1)."

\section{Superior Power User School Principal Category}

According to Table 4, two teachers produced two metaphors in the category of superior power user school principal. In this category, the metaphors of lion and building foundation were used. Below are sample statements of the teachers who produced the metaphors in this category.

"The headmaster is like a lion. Because the lion is the leader of the forest and the school principal (T13)."

"The school principal is similar to the foundation of the building because if the foundation is not strong, the building may collapse (T16)."

\section{Acting School Principal Category}

According to Table 4, a vice-principal and a teacher produced metaphors in the acting school principal category. In this category, the metaphors of theater artist and acting person were used. Below are sample expressions of the vice-principals and teachers who produced the metaphors in this category.

"The principal is like a theater artist. Their ideas and roles change according to the game and the actor (VP3)."

"School principal is like an acting person. Because it manages the events according to the situation (T11)."

\section{The Principal as the Source of Information Category}

According to Table 4, two teachers produced two metaphors in the school principal as the source of information" category. In this category, the root of a tree and tree metaphors were used. Below are sample statements of the teachers who produced the metaphors in this category.

"The principal is like the root of the tree. Because no matter how much he develops himself, the teachers who have branches will be good and do their job lovingly (T26)."

"The principal is like a tree. Because if it can correctly convey the commands and duties of the system that brought it there to its branches (teachers and students) by using its knowledge and abilities, it will turn green and bloom, that is, a living organism becomes a useful organism. If the directorate cannot accommodate their skills and knowledge, only the trunk (wood) remains (T31)."

\section{Indispensable School Principal Category}

According to Table 4, a vice-principal produced a metaphor in the indispensable school principal category. In this category, the metaphor of the nucleus of an atom was used. Below is the sample statement of the vice-principals who produced the metaphors in this category.

"The headmaster is like the nucleus of an atom. Because it forms the basis of all of the school (VP2)."

School principalship is a place for promotion in the education system on North Cyprus. Candidate principals apply to the vacant post to enter the written examination used for selecting the right candidates. Before applying to the written exam, each candidate needs to prepare a folder to meet the predetermined criteria. The criteria to be used in calculating the criterion scores for each candidate principal for 
promotions include the level of seniority, grades of registry/inspection of years, level of education, activities on professional development, on scientific publication, and on social-cultural as well as the years being staff at the same school. To be appointed and entitled to the school principals, they need to meet the passing requirements. Being a school principal in TRNC requires meeting predetermined competencies and demands to be successful in the selection exam, having the highest criteria results, and being included in the list announced for the vacancy. It is vital how vice-principals and teachers perceive school principalship in their wishes to become school principals. Metaphors reflect thinking processes and therefore appear not only in language but also in perception (Lawrence, 2009). Arkonaç (2005) defines perception as interpreting the sensory data carried by the sensory organs and giving meaning to the stimuli in the environment.

Perception is not solely a sense. It is the end maintained through process-product after several serious studies. The brain is effective in this process. Past experiences, cultural factors, and expectations of the individual are decisive (Cüceloğlu, 1997). The school principalship considers important whether its perception aspect regarding objective facts or the aspects related to our subjective knowledge. Viceprincipals and teachers would experience the selection process after the course they attended. Most of them would become school principals. Therefore, how candidate principals perceive school principalship and how they understand the principalship concept places a significant value. The principal candidates were asked to answer and give their reasons what and why to compare the school principals through metaphoric usage. The answers received were examined one by one. The researchers calculated frequency and percentages. To consider what and why to compare the school principals through metaphors, the researchers formed the themes analyzed. These themes aided in understanding how teachers perceive the school principal.

Examining the expressions in the guiding school principal category, the candidate principals mostly use the metaphors called conductor, mirror, octopus, compass, driver, nervous system, and captain. The viceprincipals and most of the teachers see the school principalship as a guide.

School principals guide teachers and students with their behaviors, and their practices are one of the main roles expected and desired from them (Döş and Savaş, 2015; Balyer, 2013).

Again, the school principal appearing to be the conductor shows that they perceive school principals as people who coordinate and behave in harmony. Akbaşl and Diş (2019) determined that leading school principals should carry guiding spirit as part of their human characteristics. Cerit (2008) states that principals who conduct orchestration are perceived more than the shareholders who increase the quality level of educational activities, use human resources effectively, design material resources in the school, help and guide teachers and students when they need.

To examine the metaphors in the protecting school principal, the school is similar to a family, and the school principal plays the supervision role for the family. The traditional school image promotes that a traditional school is a place to protect students against external negativity and to educate them according to the desired characteristics (Cerit, 2008). This expectation shows that schools are perceived as the family and they have a role in protecting and raising children. Dağlı and Ağalday (2018) found that school principals protect teachers against unfair criticism from outside the school at the highest level.

Considering the expressions in the diligent school principal category, the school principals have an effort to meet the schools' needs, and they inevitably work for the school. The school principals loving their profession or doing their profession is fondly effective in the emergence of this result. However, a small number of teachers developing metaphors for this category are perceived deficiencies for school principals. Studies show being hardworking has been consired as one of the characteristics of the school principals (Babaoğlan, Nalbant, and Çelik, 2017; Turan, Yıldırım, and Aydoğdu, 2012).

To maintain the expressions in the negatively behaving school principal category, school principals are criticized either because of their authoritarianism or of their avoidance behaviors. Balcı (1999) found that school principals are generally defined by negative metaphors such as authoritarian principal, disciplinary principle, rude principal, harmful principal, and insensitive principal. School principals who are not satisfied with their situation and do not see themselves as teaching leaders may not demonstrate effective leadership behavior and perform effective teaching leadership.

School principals who are not satisfied with their situation and do not see themselves as teaching leaders may not demonstrate effective leadership behavior and perform effective teaching leadership.

The bridge metaphor in the balancing school principal category reflects a holistic perspective. The candidate principals perceive the principal as the person who provides the connection and liaison between all stakeholders related to the school, such as teachers, students, and parents.

The balancing school principal function of the school principalship works like a regulator in terms of ensuring organizational harmony and organizational continuity within the school. The school principal is the main key point that can keep all stakeholders together inside and outside the school. 
For this reason, the unifying feature of a school principal can be interpreted as necessary for schools and as a positive result for teachers. To examine the metaphors making up the superior power user principal category, prospective principals emphasize the power of the principal. Fennel (1996) finds the metaphors entitled powerful and ruling under the category leadership and the relational appearance of power. Aydoğdu (2008) identified the metaphors commander, king, boss, lion, and police under the school principals as an authority element category. Koşar and Çalık (2011) found that personal power is a power style used in the school principalship, but that the reward power within the office power is more important than the legal and coercive power. The legal and bureaucratic authority of the school principal supports the power factor.

To consider the metaphors constituting the acting school principal category, school principals behave differently depending on the situation. Korkmaz and Çevik (2018) found that principalship understanding of the school principals is inconsistent and changing. To examine the metaphors indispensable school principal category, a least produced metaphorical category of the current study, the candidate principals perceive the principal as the source of absolute necessity at the school and as the source of energy. The importance of school principalship arises from the tasks of the administration. The school administration requires to keep the organization alive by following per objectives under the teachers' act. It also emphasizes the importance of school management, the authority, and the responsibility of the school administrator (Bursalığlu, 2000). However, the indispensability can turn into a dangerous situation like a development watchdog for the teacher (Bredeson, 2000).

Comparing all categories with Ylldız and Ertürk's findings (2019), the principal is a leader only in the guiding school principal category. Various produced categories show similar characteristics to the features of the classic principalship features. In this respect, the candidate principals need to develop their competencies areas, like innovation, vision, strategic management, and administration.

\section{Results and Conclusions}

The current study aims at determining the metaphoric perceptions of the candidate principals. For this purpose, the metaphors produced for the concept of school principalship grouped under nine conceptual categories. Each metaphor used in this study reveals different perceptions about the principals. Various terms about who the school principals are, how they work, and what their duties are defined. The provided metaphorical definitions of school principalship may promote a better understanding of how to be a better school principal.

Examining findings in the current study, the candidate principals see the school principals as the guiding leaders. In this respect, a school principal is a role model, an example for candidate principals, and most of them act as a conductor.

To understand the findings, the candidate school principals perceive the school principal as a guiding leader. In this respect, we can say that school principals are an example for principal candidates, and most of them act as a conductor when they become school principals. As a result of the research, the perceptions of the principal candidates about the school principalship are generally positive. However, using the negative perception, school principals should undergo a series of in-service training. Negative perceptions show that the development of the school is to be insufficient in the education system, which conversely may cause the principal to become inadequate in other schools by taking that principal as an example. The school principal is the place of work. It is not just a place to skip status, increase income, or act on your own. Among the metaphors, the school principals mostly carry out technical or hierarchical processes. There are no metaphors produced on school culture, human relations, innovation, entrepreneurship, and sustainability.

\section{Recommendations}

Since the candidate principals will be the future principals throughout the education system of North Cyprus, pieces of in-service training require designing how to promote positive perceptions of the school principals. The number of studies on the desire of vice-principals and teachers to be school principals should be increased. Vice-principals' and teachers' aspirations to be school principals should be managed in a healthy way to support the school and to motivate teachers.

\section{References}

Abdal, G. (2017). Bejan Matur çevirileri: Metaforik yeniden yazma (Publication No: 467337). [Master's theses, Istanbul University]. https://tez.yok.gov.tr/UlusalTezMerkezi/tezSorguSonucYeni.jsp

Akan, D., Yıldırım, I, \& Yalçın, S. (2014). Öğretmenlerin algıladıkları yönetici yeterlik davranışları ile ilköğretim kurumları yöneticilerinin ilişkilerle ilgili bilişsel çarpıtmaları arasındaki ilişsi. Uşak 
Üniversitesi Sosyal Bilimler Dergisi, 7(3), 187-207.

https://dergipark.org.tr/tr/pub/usaksosbil/issue/21657/232858

Akbaşlı, S, Üredi, L, Yolcu, H., K., \& Loğoğlu, P. (2017). Ortaokul öğrencilerinin Matematik öğretmeni ve Matematik dersine yönelik metaforik algılarının incelenmesi . Kastamonu Eğitim Dergisi, 25 (6) , 2283-2294 . https://dergipark.org.tr/en/pub/kefdergi/issue/31577/357338

Akbaşlı, S., \& Diş, O. (2019). Öğretmen görüşleri doğrultusunda lider okul yöneticilerinin yeterlikleri. Uluslararası Liderlik Çalışmaları Dergisi, 2(2), 86-102

Akyol, B., \& Kapçak, C. (2017). Pre-service teachers' perceptions of "Administration" and "School Principal" reflected through metaphors. European Journal of Education Studies, 3(10), 293-309. http://dx.doi.org/10.46827/ejes.v0i0.1096

Arkonaç, S. A., (2005). Psikoloji: Zihin süreçleri bilimi (4. Baskı). İstanbul: Alfa Yayınları.

Aslan, O., Bilgili, A., \& Kaya, A. (2018). Liselerde okuyan öğrencilerin okul müdürüne ilişkin metaforik algıları. Bilim Armonisi, 1(1), 11-17. https://dergipark.org.tr/en/pub/bilar/issue/41115/500255

Aydoğdu, E. (2008). İlköğretim okullarındaki ögrenci ve öğretmenlerin sahip oldukları okul algıları ile ideal okul algilarınin metaforlar (mecazlar) yardımiyla analizi (Publication No: 177265). [Master's theses, Osman Gazi University]. https://tez.yok.gov.tr/UlusalTezMerkezi/tezSorguSonucYeni.jsp

Babaoğlan, E., Nalbant, A., \& Çelik, E. (2017). Okul başarısına okul yöneticisinin etkisine ilişkin öğretmen görüşleri. Mehmet Akif Ersoy Üniversitesi Eğitim Fakültesi Dergisi, 43, 93-109. http://doi.org/10.21764/efd.82932

Balc1, A. (1999). Metaphorical images of school: School perceptions of students, teachers, and parents from four selected schools (Publication No: 82164). [Doctoral dissertation, Midde East Technical University]. https://tez.yok.gov.tr/UlusalTezMerkezi/tezSorguSonucYeni.jsp

Balyer, A. (2013). Okul müdürlerinin öğretimin kalitesi üzerine etkileri. Kuram ve Uygulamada Eğitim Yönetimi, 19(2), 181-214. https://dergipark.org.tr/en/pub/kuey/issue/10320/126561

Beck, L., \& Murphy, J. (1993). Understanding the principalship:Metaphorical themes, 1920s-1990s. NewYork: Teachers College Press.

Black, M. (1979). More about metaphor in ortony: A metaphor and thought. Cambridge: Cambridge University Press

Botha, E. (2009). Why metaphor matters in education. South African Journal of Education. 29, 431444. $10.15700 /$ saje.v29n4a287

Brandt, N. C. (2004). Constructing school organization through metaphor: Making sense of school reform (Publication No: 3130). [Doctoral dissertation, Florida State University]. Theses and Dissertation FSU. http://purl.flvc.org/fsu/fd/FSU_migr_etd-3130

Brooks, J. S., \& Normore, A. H. (2010). Educational Leadership and Globalization: Literacy for a Global Perspective. Educational Policy, 24(1), 52-82. https://doi.org/10.1177/0895904809354070

Bredeson, P. V. (2000). The school principal's role in teacher professional development. Journal of InService Education, 26(2), 385-401. https://doi.org/10.1080/13674580000200114

Bursalıoğlu, Z. (2000). Okul yönetiminde yeni yapı ve davranış (11. Ed.). Ankara: PegemA Yayıncılık.

Carpenter, J. (2008). Metaphors in qualitative research: Shedding light or casting shadows? Research in Nursing and Health, 31, 274-282. https://doi.org/10.1002/nur.20253

Cerit, Y. (2008). Students, teachers and administrators' views on metaphors with respect to the concept of principal. Education and Science, 33(147), 3-13

Chatelain-Ponroy, S. (2010, August). A new metaphor for understanding management control practices. International Federation of Scholarly Associations of Management. "Justice and Sustainability in the Global Economy". France. pp.actes en ligne. https://halshs.archives-ouvertes.fr/halshs00502413/document

Cüceloğlu, D. (1997). İnsan ve davranışı:Psikolojinin temel kavramları. İstanbul: Remzi Kitapevi

Creswell, J. W. (2003). Research design: Qualitative, quantitative, and mixed method approaches (2. Ed.). Sage Publication Thousand Oaks, California

Çobanoğlu, N., \& Gökalp, S. (2015). Öğretmen adaylarının okul müdürüne ilişkin metaforik algıları. Mustafa Kemal Üniversitesi Sosyal Bilimler Enstitüsü Dergisi, 12(31), 279-295. https://dergipark.org.tr/en/pub/mkusbed/issue/19577/208812

Dağlı, A., \& Ağalday, B. (2018). Okul müdürlerinin paternalist liderlik davranışlarının incelenmesi. Elektronik Sosyal Bilimler Dergisi, 17(66), 518-534. https://doi.org/10.17755/esosder.341663

Demirtaş, H., \& Özer, N. (2014). Okul müdürlerinin bakış açısıyla okul müdürlüğ̈̈. Kastamonu Eğitim Dergisi, 22(1), 1-24. https://dergipark.org.tr/tr/pub/kefdergi/issue/22603/241527

Döss, İ. \& Savaş, A.C. (2015). Elementary school administrators and their roles in the context of effective Schools. SAGE Open, 1-11. https://doi.org/10.1177/2158244014567400 
Elo, S., \& Kyngäs, H. (2008). The qualitative content analysis process. Journal of Advanced Nursing, 62, 107115.

eohd.mebnet.net (2020). 2019-2020 Statistical yearbook. http://eohd.mebnet.net/sites/default/files/2019-2020\%20MEKB\%20IstatistikYilligi.pdf

Fennel, H. A. (1996, August). An exploration of principals' metaphors for leaders and power (No: ED399626). https://files.eric.ed.gov/fulltext/ED399626.pdf

Graneheim, U. H., \& Lundman, B. (2004). Qualitative content analysis in nursing research: Concepts, procedures and measures to achieve trustworthiness. Nurse Education Today, 24(2), 105-112. https://doi.org/10.1016/j.nedt.2003.10.001

Hogler, R., Gross, M. A., Hartman, J. L., \& Cunliffe, A. L. (2008). Meaning in organizational communication: Why metaphor is the cake, not the icing. Management Communication Quarterly. 21(3), 393-412. https://doi.org/10.1177/0893318907309929

Itkin, H., \& Nagy, M. (2014). Theoretical and practical use of metaphors in organizational development and beyond. Pannon Management Review, 3(4), 37-72

Jones, D., M., B. (2002). Models, metaphors and analogies. In P. Machamer and M.Silberstein (Eds.), The Blackwell guide to the Philosophy of Science (pp. 108-127). Blackwell

Publishers. https://doi.org/10.1002/9780470756614.ch6

Korkmaz, M., \& Çevik, M. S. (2018). Ortaokul öğretmenlerinin müdür kavramına ilișkin metaforik algıları. Kuramsal Eğitimbilim Dergisi [Journal of Theoretical Educational Science], 11(4), 973-1002. http://dx.doi.org/10.30831/akukeg.393339

Koşar, S., \& Çalık, T. (2011). Okul yöneticilerinin yönetimde gücü kullanma stilleri ile örgüt kültürü arasındaki ilişki. Kuram ve Uygulamada Eğitim Yönetimi [Educational Administration: Theory and Practice], 17(4), 581-603.

Lakoff, G., \& Johnson, M. (2003). Metaphors we live by (2. Ed.). Chicago: The University of Chicago Press.

Lawrence E. M. (2009). On perceptual metaphors. Metaphor and Symbolic Activity, 11(1), 3966. https://doi.org/10.1207/s15327868ms11013

Low, G. (2008). Metaphor and education. In R. Gibbs, Jr. (Ed.), The Cambridge handbook of metaphor and thought (Cambridge Handbooks in Psychology, pp. 212-231). Cambridge: Cambridge University Press. https://doi.org/10.1017/CB09780511816802.014

Lunenburg, F. C., \& Ornstein, A.C. (2012). Educational administration (6. Ed.). Belmont, CA: Wadsworth Cengage Learning.

Merriam S. B. (2009). Qualitative research: A guide to design and implementation. (3. Ed.). San Francisco, CA: Jossey-Bass.

Miles, M., \& Huberman, A. M. (1994). Qualitative data analysis: An expanded sourcebook (2. Ed.). Thousand Oaks, CA: Sage Publications.

Morgan, G. (1997). Images of organization. Thousand Oaks, CA: Sage Publications.

Moustakas, C. (1994). Phenomenological research methods. Thousand Oaks, CA: Sage Publications. https://dx.doi.org/10.4135/9781412995658

Ortony, A. (1975). Why metaphors are necessary and not just nice educational theory, 25(1), 45-53. https://doi.org/10.1111/j.1741-5446.1975.tb00666.x

Örücü, D. (2014). Öğretmen adaylarının okul, okul yönetimi ve Türk eğitim sistemine yönelik metaforik algıları. Kuram ve Uygulamada Eğitim Yönetimi, 20(3), 327-358.

Patton, M. Q. (2002). Qualitative Research and Evaluation Methods (3. Ed.). Thousand Oaks, CA: Sage Publications.

Polit, D. F., \& Beck, C. T. (2012). Nursing research: Principles and methods. Philadelphia, PA: Lippincott Williams \& Wilkins.

Sandelowski, M. (1998). Writing a good read: Strategies for representing qualitative data. Research'in Nursing \& Health, 21, 375-382. https://doi.org/10.1002/(SICI)1098-240X(199808)21:4<375::AIDNUR9>3.0.CO;2-C

Schreier, M. (2012). Qualitative content analysis in practice. Thousand Oaks, CA: Sage.

Şahin, D., \& Tüzel, E. (2014). İlköğretim birinci kademe öğrencilerinin okul yöneticilerine ilişkin metaforları. Adıyaman Üniversitesi Sosyal Bilimler Enstitüsü Dergisi, 17, 355-396. https://doi.org/10.14520/adyusbd.736

Tomlinson, H. (2004). Educational Management: Major Themes in Education. London: RoutledgeFalmer

Turan, S., Yıldırım, N., \& Aydoğdu, E. (2012). Okul müdürlerinin kendi görevlerine ilişkin bakış açıları. Pegem Ĕgitim ve Öğretim Dergisi, 2(3), 63-76

Ylldız, K., \& Ertürk, R. (2019). Yönetici ve lider kavramlarına iliş̧kin öğretmen görüşleri: Bir metafor çalışması. Abant İzzet Baysal Üniversitesi Eğitim Fakültesi Dergisi, 19(4), 1190-1216. https://doi.org/10.17240/aibuefd.2019.19.47159-574232 
Yükselme Sınavını Oluşturan Testlerin Kapsamı (2019, 28 Şubat). Resmî Gazete (Sayı:148 (Ek III Tebliğler ve İlanlar). http://arsiv.basimevi.gov.ct.tr/Portals/105/2019/27.pdf?ver=2019-03-01-114149-567 